\title{
Pembentukan Karakter Peserta Didik Melalui Pembelajaran Matematika
}

\author{
Suparni \\ Program Studi Pendidikan Matematika, Fakultas Sains dan Teknologi, UIN Sunan Kalijaga, \\ Jl. Marsda Adisucipto No. 1 Yogyakarta 55281, Indonesia
}

Korespondensi; Email: suparni71@yahoo.com

\begin{abstract}
Abstrak
Membangun karakter tidak hanya sebagai isu pengembangan pendidikan, tapi juga sebagai proses membangun moral warga. Pengembangan karakter sebagai fokus pendidikan di semua jenjang pendidikan mulai dari sekolah dasar hingga universitas memberikan perhatian yang tinggi. Pendidikan matematika tidak bisa lepas dari matematika. Jadi, Jika kita ingin membangun karakter siswa, kita harus menggunakan nilai filosofi pendidikan matematika dengan cara mengamalkan karakteristik matematika karena objeknya abstrak, simbol itu tidak ada artinya, kesepakatan tercapai dan pemikiran aksiomatik deduktif, dan tidak kontradiktif. Ada banyak nilai karakter dalam pengajaran matematika yang berhubungan dengan karakteristik matematika yang bisa diintegrasikan dengan Al Qur'an yang kita harapkan dapat mendukung tujuan pendidikan nasional, seperti kesepakatan yang dicapai, konsisten, deduksi dan utuh. Karakter siswa dapat dibangun dengan pengajaran matematika sebagai agama, kebenaran, toleransi, disiplin, kreatif, demokratis, masuk akal untuk mengetahui, kebangsaan, dan komunikatif.
\end{abstract}

Kata Kunci: Pembentukan karakter; Nilai karakter; Pembelajaran matematika

\begin{abstract}
Character building not only as an issue of education development, but also as a process of citizen moral building. Character building as an education focus in all of education level from elementary school into university spend a high attention. Mathematics education can't release from mathematics. So, If we want to build the student character, we must be use the philosophies values of mathematics education by expression the characteristic of mathematics as the object is abstract, the symbol is no meaning, agreement reached and deductive axiomatic thinking, and non contradiction. There are many character value in the mathematics instruction that related with the characteristic of mathematics that can be integrated with Al Qur'an that we hope can support national education purposes, as agreement reached, consistent, deduction and whole. The student character can be build by mathematics instruction as religious, truth, tolerance, discipline, creative, democratic, sense to know, nationality, and communicative.
\end{abstract}

Keywords: Character building; Character value; Mathematics instruction

\section{Pendahuluan}

Dalam setiap pembahasan tentang pendidikan matematika, tidak akan terlepas dari pendidikan dalam arti luas. Pada kenyataannya, masalah pendidikan adalah salah satu bagian dari masalah- masalah pembangunan. Oleh karena itu, gerak langkah pendidikan tidaklah dapat dilepaskan dari arus perkembangan yang ada dalam masyarakat yang sedang membangun.

Pertama, perkembangan sains dan teknologi beserta produknya. Perkembangan sains dan teknologi dewasa ini sudah jelas menimbulkan tuntutan-tuntutan tertentu terhadap pendidikan kita. Berbagai usaha sudah dilakukan oleh berbagai pihak untuk mengadakan penyesuaian diri dengan perkembangan tersebut. Penyesuaian yang tidak selektif tentu akan menimbulkan ketidakseimbangan. Kita tidak mungkin membendung arus kemajuan teknologi dewasa ini, tetapi kita harus menanggapi secara bertanggungjawab untuk kepentingan pendidikan dewasa ini dan di masa yang akan datang. Kita jangan hanya sekedar menjadi konsumen produk teknologi dari negara lain, tetapi kita harus mampu 
mengambil alih peran sebagai produsen ilmu dan teknologi secara berencana dan mendasar. Artinya bahwa pengelolaan pendidikan kita perlu selalu tanggap akan kemajuan yang ada secara bertanggungjawab.

Kedua, tuntutan kuantitas dan kualitas produk pendidikan. Tuntutan kuantitas dari produk pendidikan dapat diamati pada beberapa jenjang pendidikan. Berbagai macam argumentasi/alasan agaknya mendukung keputusan mengapa harus memenuhi tuntutan tersebut. Banyaknya calon peserta didik baru yang akan memerlukan tempat, merupakan salah satu alasan untuk meluluskan sebanyak mungkin peserta didik pada kelas tertinggi. Adanya kekhawatiran akan kehilangan nama baik sekolah, tingkah laku peserta didik jika tidak diluluskan, juga merupakan alasan untuk meluluskan sebanyak mungkin peserta didik kelas tertinggi. Dengan membanjirnya produk pendidikan seperti ini, berakibat semakin meningkatmnya lulusan yang tidak mampu melanjutkan pendidikan ke jenjang yang lebih tinggi atau bekerja. Kemerosotan mutu tersebut berakibat jauh pada ketidakmampuan menerapkan pengetahuan yang diperoleh, menciptakan lapangan kerja sendiri, dan lain-lain.

Ketiga, teori pendidikan dan kenyataan di lapangan. Berbagai teori didapatkan calon guru selama mengikuti pendidikan, terutama yang berkaitan langsung dengan proses belajar mengajar di kelas. Teori belajar yang berkaitan dengan berbagai metode mengajar, teori evaluasi dengan berbagai alat ukurnya, teori pengelolaan kelas, dan lain-lain adalah bekal yang diharapkan dapat meningkatkan mutu guru yang pada gilirannya diharapkan dapat meningkatkan mutu produk pendidikan.

Agar Indonesia memiliki cukup warga negara yang berkualitas tinggi diperlukan sumber daya manusia yang berkualiltas yang mampu menguasai dan mengembangkan ilmu pengetahuan dan teknologi, dapat memanfaatkannya untuk kesejahteraan seluruh bangsa serta dapat menangkal pengaruh negatifnya.

Pendidikan karakter akhir-akhir ini memang menjadi isu utama pendidikan, selain menjadi bagian dari proses pembentukan akhlak anak bangsa. Pendidikan karakter menjadi fokus di seluruh jenjang pendidikan dari pendidikan dasar, menengah, hingga di pendidikan tinggi, serta mendapatkan perhatian yang cukup besar. Pendidikan karakter ini juga diperjelas melalui UU No 20 tahun 2003 tentang Sistem Pendidikan Nasional, yang berbunyi "Pendidikan nasional berfungsi mengembangkan kemampuan dan membentuk watak serta peradaban bangsa yang bermartabat dalam rangka mencerdaskan kehidupan bangsa, bertujuan untuk berkembangnya potensi peserta didik agar menjadi manusia yang beriman dan bertakwa kepada Tuhan Yang Maha Esa, berakhlak mulia, sehat, berilmu, cakap, kreatif, mandiri, dan menjadi warga negara yang demokrasi serta bertanggung jawab." [12]

Pada dasarnya pembentukan karakter dimulai dari fitrah yang diberikan Illahi, yang kemudian membentuk jati diri dan perilaku. Dalam prosesnya sendiri fitrah Illahi ini sangat dipengaruhi oleh keadaan lingkungan, sehingga lingkungan memilki peranan yang cukup besar dalam membentuk jati diri dan perilaku. Pendidikan karakter ini tidak dijadikan kurikulum yang baku, melainkan dibiasakan melalui proses pembelajaran. Selain itu mengenai sarana-prasarana, pendidikan karakter ini tidak memiliki sarana-prasarana yang istimewa, karena yang diperlukan adalah proses penyadaran dan pembiasaan.

Kenyataanya, banyak peserta didik yang unggul dalam prestasinya tetapi masih rendah dalam keimanan dan ketaqwaannya yang terwujud dalam moralnya. Banyak terjadi tawuran di antara pelajar yang hanya dipicu oleh masalah yang sebenarnya hanya sepele. Hal ini salah satunya disebabkan oleh pendidikan yang cenderung menekankan pada sisi materi pelajaran sangat kurang menanamkan nilai- nilai moral dan etika pada pembelajaran. Oleh karena itu, pendidikan karakter harus ditanamkan sejak dini dari pendidikan dasar dengan diimplementasikan dalam setiap pembelajaran termasuk pembelajaran matematika.

\section{Rumusan Masalah}

Berdasarkan pada latar belakang tersebut di atas, maka dalam makalah ini dapat dirumuskan permasalahan sebagai berikut.

Bagaimanakah pembentukan karakter peserta didik melalui pembelajaran matematika? 


\section{Tujuan}

Berdasarkan rumusan masalah tersebut di atas, maka penulisan makalah ini bertujuan untuk menelaah secara mendalam pembelajaran matematika yang dapat membantu dalam pembentukan karakter peserta didik.

\section{Pembahasan}

Dalam makalah ini akan disajikan beberapa contoh materi dalam pembelajaran matematika yang diharapkan dapat menanamkan nilai moral dan etika. Karakteristik dari pembelajaran matematika diharapkan dapat membentuk karakter peserta didik. Hal ini selanjutnya semakin memperbaiki moral bangsa sehingga tercapai tujuan pendidikan nasional yaitu mewujudkan insan yang beriman dan bertakwa kepada Tuhan Yang Maha Esa, berakhlak mulia, sehat, dan berilmu.

Satu-satunya wadah kegiatan yang dapat dipandang dan seyogyanya berfungsi sebagai wadah untuk menciptakan sumber daya manusia yang bermutu tinggi adalah pendidikan, baik pendidikan jalur sekolah maupun jalur luar sekolah. Matematika sebagai salah satu ilmu dasar baik aspek terapan maupun aspek penalarannya, mempunyai peranan yang penting dalam upaya penguasaan ilmu pengetahuan dan teknologi. Ini berarti bahwa sampai pada batas tertentu matematika perlu dikuasai oleh segenap warga negara Indonesia, baik penerapannya maupun pola pikirnya [5]. Matematika sekolah yang merupakan bagian dari matemaika yang dipilih atas dasar kepentingan pengembangan kemampuan dan kepribadian peserta didik serta perkembangan ilmu pengetahuan dan teknologi perlu selalu dapat sejalan dengan tuntutan kepentingan peserta didik menghadapi tantangan kehidupan masa depan.

\section{Pendidikan Matematika}

Pendidikan matematika tidak dapat terlepas dari matematika itu sendiri. Oleh karena itu, untuk membentuk karakter peserta didik sehingga dapat meningkatkan keimanan dan ketakwaan dengan menggunakan nilai-nilai filosofis pendidikan matematika akan lebih baik jika terlebih dahulu mengungkap karakteristik dari matematika. Karakteristik matematika yaitu obyeknya yang abstrak, simbol yang kosong dari arti, kesepakatan dan pemikiran deduktif aksiomatik, dan anti kontradiksi [4].

1. Obyek matematika adalah abstrak.

Obyek langsung dari matematika adalah "fakta", "konsep", "operasi", dan "prinsip" yang semuanya adalah abstrak. Sedangkan obyek tidak langsung di antaranya berupa kemampuan membuktikan teorema, kemampuan pemecahan masalah, transfer belajar, balajar tentang belajar, kemampuan inkuiri, dan disiplin diri [4]. Objek matematika adalah abstrak dan hanya ada dalam pemikiran manusia, sehingga tidak dapat disentuh atau diraba, yang dapat kita amati hanyalah simbol dari objek matematika.

Fakta dalam matematika adalah suatu kesepakatan yang disajikan dalam bentuk kata-kata atau simbol. Kita sudah terbiasa dengan simbol "2" dan kata "dua". Pada saat kita mengatakan "dua" dengan sendirinya tergambar simbol "2", demikian sebaliknya, jika kita disodori simbol "2" dengan sendirinya kita memadankan dengan kata "dua". Kaitan simbol "2" dengan kata dua ini merupakan fakta. Konsep dalam matematika adalah ide abstrak untuk membantu mengklasifikasikan objek-objek atau benda-benda dan untuk menentukan apakah objek-objek atau benda-benda adalah contoh atau bukan contoh dari ide abstrak tersebut. Pengertian "dua" itu sendiri adalah konsep yang secara matematika diabstraksikan dari adanya ekivalensi antar himpunan-himpunan. Skill dalam matematika adalah himpunan aturan dan perintah atau prosedur tertentu yang dikenal dengan algoritma. Untuk menunjukkan konsep tertentu digunakan batasan atau definisi. Prinsip dalam matematika adalah objek matematika yang lebih kompleks yang menyatakan keterkaitan antara dua atau lebih objek matematika.

2. Simbol yang kosong dari arti

Objek matematika yang abstrak dituangkan dalam simbol-simbol. Simbol-simbol inilah yang akhirnyamembentuk bahasa matematika. Bahasa matematika secara sederhana dapat digunakan 
sebagai sarana berkomunikasi, sarana tempat berpikir, dan mengekspresikan ide-ide secara teratur dan sistematis.

Menurut Soedjadi simbol-simbol dalam matematika pada umumnya masih "kosong dari arti" sehingga dapat diberikan arti kepada simbol-simbol itu sendiri sesuai dengan lingkup dan semestanya.

Keberadaan simbol ini memberi peluang yang besar kepada matematika untuk digunakan dalam berbagai ilmu dan kehidupan nyata [4].

\section{Kesepakatan dan pemikiran deduktif aksiomatik}

Dari kedua karakteristik yang telah diuraikan di atas dapat disimpulkan bahwa dalam matematika terdapat banyak kesepakatan. Selain itu, dalam kehidupan sehari-hari pun sering dijumpai banyak kesepakatan-kesepakatan yang tertulis maupun kesepakatan yang tidak tertulis.

Selanjutnya yang dimaksud dengan metode aksiomatik adalah pembenaran pernyataan $\mathrm{P}_{1}$ dengan menggunakan pernyataan $\mathrm{P}_{2}$ yang sebelumnya telah diterim benar. Sedangkan pembenaran pernyataan $\mathrm{P}_{2}$ dengan menggunakan pernyataan $\mathrm{P}_{3}$ yang sebelumnya telah diterima benar pula. Demikian seterusnya sehingga sampai pada suatu pernyataan $\mathrm{P}_{0}$ yang tidak lagi perlu pembuktian. Pernyataan $\mathrm{P}_{0}$ inilah yang disebut aksioma. Oleh karena aksioma digunakan selalu mempunyai sifat umum dan kemudian dapat diturunkan hingga memperoleh sifat-sifat khusus, maka struktur ini disebut pula berpola deduktif. Dan ini merupakan satu-satunya pola pikir yang diterima dalam matematika.

\section{Konsisten}

Setiap pernyataan atau definisi dalam matematika harus menggunakan istilah atau konsep terdahulu secara konsisten. Konsisten dalam arti maupun dalam nilai kebenarannya. Objek matematika yang abstrak tersebut disajikan di sekolah sesuai dengan kemampuan penalaran peserta didik. Hal inilah yang membuat objek matematika yang dipelajari diturunkan tingkat keabstrakannya agar mudah dipelajari dan dapat tertanam lama dalam pemikiran peserta didik.

Tujuan pendidikan matematika dapat dilihat dengan tujuan kurikulum yang tertuang dalam setiap kurikulum masing-masing jenjang sekolah. Perumusan tujuan tersebut pastilah diusahakan untuk menopang tujuan institusional masing-masing jenis sekolah, dan tujuan pendidikan nasional sebagaimana tertuang dalam tap MPR. Selain itu tujuan kurikuler tersebut mengacu kepada teori Bloom tentang tujuan pendidikan yaitu meliputi ranah kognitif, afektif, dan psikomotor.

Tujuan Pendidikan Nasional tertuang dalam UU no 20 tahun 2003 yaitu Pendidikan Nasional berfungsi mengembangkan kemampuan dan membentuk watak serta peradaban bangsa yang bermartabat dalam rangka mencerdaskan kehidupan bangsa, bertujuan untuk berkembangnya potensi peserta didik agar menjadi manusia yang beriman dan bertakwa kepada Tuhan Yang Maha Esa, berakhlak mulia, sehat, berilmu, cakap, kreatif, mandiri, dan menjadi warga negara yang demokratis serta bertanggung jawab [12].

Tujuan pendidikan Matematika mulai dari SD hingga sekolah menengah atas adalah agar peserta didik memiliki kemampuan sebagai berikut [2]:

a. Memahami konsep matematika, menjelaskan keterkaitan antar konsep dan mengaplikasikan konsep atau algoritma secara luwes, akurat, efisien, dan tepat dalam pemecahan masalah

b. Menggunakan penalaran pada pola dan sifat, melakukan manipulasi matematika dalam membuat generalisasi, menyusun bukti, atau menjelaskan gagasan dan pernyataan matematika.

c. Memecahkan masalah yang meliputi kemampuan memahami masalah merancang model matematika, menyelesaikan modeldan menafsirkan solusi yang diperoleh.

d. Mengomunikasikan gagasan dengan simbol, tabel, diagram, atau media lain untuk memperjelas keadaan atau masalah.

e. Memiliki sikap menghargai kegunaan matematika dalam kehidupan, yaitu memiliki rasa ingin tahu, perhatian, dan minat dalam mempelajari matematika, serta sikap ulet dan percaya diri dalam pemecahan masalah.

Untuk keperluan proses belajar mengajar di dalam kelas, tujuan kurikuler tersebut masih perlu dijabarkan ke dalam tujuan institusional (SK, dan KD). Pada tahap ini, kesulitan akan dialami terutama dalam usaha memadukan ranah afektif dan psikomotor sehingga dewasa ini lebih diperhatikan hanya 
pada ranah kognitif saja. Hal ini tentu akan mempengaruhi proses belajar mengajar di kelas yang tentunya juga akan mempengaruhi pendidikan matematika yang memuat nilai-nilai luhur.

Dengan menyelaraskan dan memadukan tujuan pembelajaran dari ranah kognitif, afektif, dan psikomotor, maka akan semakin meningkatkan keimanan dan ketaqwaan peserta didik pada Tuhan Yang Maha Esa yang merupakan salah satu aspek tujuan pendidikan yaitu mengembangkan kemampuan dan membentuk watak serta peradaban bangsa yang bermartabat. Untuk mewujudkan tujuan tersebut salah satunya adalah melalui pendidikan matematika, yaitu dengan mengintegrasikan beberapa nilainilai kepribadian pada materi matematika.

Pendidikan akan melatih dan mengasah nalar manusia, sehingga dengan pendidikan maka kita akan semakin terbuka wawasan terhadap segala sesuatu yang ada di dunia ini. Nilai moral dari suatu materi pendidikan adalah keyakinan dari suatu individu atau budaya yang subjektif dan mungkin berbeda-beda bagi setiap orang dan budaya. Nilai moral seseorang dapat berkembang dan berubahubah setiap saat, sedangkan nilai moral dari suatu budaya yang terbagi atau diperlakukan sama bagi semua anggota atau kelompok berbeda dengan kelompok yang lainnya. Untuk menanamkan nilainilai dari moral pendidikan dapat diterapkan melalui pembelajaran matematika.

Pemilihan bagian-bagian dari matematika untuk matematika sekolah tersebut perlu selalu disesuaikan dengan perkembangan dan tantangan masa depan. Hal in berarti bahwa tujuan pendidikan matematika untuk masa depan harus memperhatikan (1) tujuan yang bersifat formal, yaitu penataan nalar dan pembentukan kepribadian anak, dan (2) tujuan yang bersifat material yaitu penerapan matematika serta ketrampilan matematika.

Matematika sekolah yang diajarkan di setiap jenjang pendidikan tertentu harus dengan jelas dapat mendukung upaya pencapaian tujuan pendidikan nasional. Hal ini berarti bahwa setiap materi yang akan diajarkan harus dapat ditunjukkan aspek-aspek tertentu yang mengandung nilai dalam mendidik peserta didik. Tujuan pendidikan matematika memiliki sifat formal dan material yang berarti bahwa pendidikan matematika harus memiliki nilai didik dan nilai praktis.

Ada beberapa nilai didik dalam pembelajaran matematika yang berkaitan dengan karakteristik dari matematika yang dapat diintegrasikan dengan Al-Quran yang diharapkan dapat mendukung tujuan pendidikan nasional, di antaranya:

1. Kesepakatan

Setiap orang yang mempelajari matematika secara sadar atau tidak sadar telah menggunakan kesepakatan-kesepakatan tertentu. Kesepakatan ini terdapat dalam matematika yang rendah maupun yang tinggi, dapat berupa simbol, istilah, definisi, ataupun aksioma.

Contoh.

a. Penggunaan simbol bilangan 1, 2, 3, 4, ... dan seterusnya.

b. Pengertian tentang persegi

c. Pengertian tentang titik, garis, lengkungan, dan lain-lain

Dalam kehidupan sehari-hari, kadang tanpa kita sadari ada banyak kesepakatan berupa normanorma baik yang tertulis maupun yang tidak tertulis yang harus dipatuhi oleh warga masyarakat dalam lingkungan tertentu. Jika seseorang berperilaku tidak sesuai dengan suatu kesepakatan dalam lingkungan tertentu, pastilah akan dianggap melanggar aturan yang tentu akan mendapatkan sangsi tertentu. Seseorang yang telah dibiasakan belajar matematika yang penuh dengan kesepakatan yang harus ditaati, pastinya akan mudah memahami perlunya kesepakatan dalam hubungan masyarakat dan mempunyai kesadaran yang lebih tinggi untuk mentaati kesepakatan tersebut. Nilai inilah yang dapat ditanamkan dalam pembelajaran matematika.

2. Ketaatasasan/konsistensi

Dalam pembahasan ini yang dimaksud dengan ketaatasasan/konsistensi adalah tidak dibenarkannya adanya kontradiksi sesuai dengan karakteristik dari matematika sendiri.

Contohnya, Untuk setiap anggota himpunan bilangan bulat, berlaku bahwa jumlah dari 2 bilangan bulat adalah bilangan bulat. Maka hasil dari $3+7$ haruslah bilangan bulat.

Dalam kehidupan sehari-hari sangat diperlukan adanya sikap dan nilai konsistensi ini, sehingga tidak akan banyak terjadi benturan-benturan dalam berhubungan dengan anggota masyarakat. Dalam kehidupan berbangsa dan bernegara telah ada aturan atau undang-undag yang harus ditaati oleh segenap warga Indonesia. Jika setiap warga negara telah terbiasa dengan berpikir matematika maka tidak akan banyak orang-orang yang melanggar aturan, sehingga tercipta negara yang aman dan 
damai. Oleh karena itu, setiap materi dalam pembelajaran matematika harus dapat menanamkan nilai konsistensi ini untuk membentuk tata nalar dan kepribadian peserta didik.

3. Deduksi

Secara sederhana, sesuai dengan karakteristik dari matematika, makna deduksi adalah proses menurunkan atau menerapkan pengertian atau sifat umum ke dalam keadaan khusus. Dalam pembahasan matematika, pola pikir deduktif inilah yang dapat diterima. Pola pikir induktif, sebenarnya juga dapat diterima sepanjang diperlukan untuk menyesuaikan bahan ajar dengan perkembangan intelektual peserta didik.

Contoh.

a. Misalnya pengertian tentang segitiga sama sisi. Ada yang mengartikan adalah segitiga yang ketiga sisinya sama ukurannya, ada juga yang mengartikan ketiga sudutnya sama ukurannya.

Dari kedua pengertian di atas maka tidak bisa keduanya digunakan secara bersama-sama sebagai definisi, salah satu harus diturunkan sebagai teorema.

b. Adanya pengertian pangkal dalam matematika akan dengan mudah kita pahami dalam membuat struktur deduksi matematika. Misalnya pengertian titik dan garis.

Dalam kehidupan berbangsa dan bernegara, segala peraturan perundang-undangan diatur secara hirarkhis mulai dari Pancasila, UUD 1945, UU, Perpu, PP, Keppres, Kepmen, dan seterusnya. Dalam hal ini, peraturan di bawahnya merupakan penjabaran dari peraturan di atasnya atau yang lebih tinggi. Kebenaran dari peraturan yang satu tentunya merujuk kepada kebenaran peraturan yang di atasnya. Dengan demikian, jelaslah bahwa dalam kehidupan berbangsa dan bernegara juga diperlukan pola pikir deduktif.

4. Semesta

Salah satu karakteristik dari matematika yaitu simbol-simbol yang dikosongkan dari maknanya. Misalnya, apakah arti x, y, z, itu? Hal ini dapat diartikan bermacam-macam tergantung si pemakai, apakah bilangan, vektor, pernyataan, atau yang lainnya. Hal ini, menunjukkan adanya lingkup pembelajaran yang dapat juga disebut semesta pembicaraan. Dalam pembelajaran matematika disadari atau tidak terdapat contoh atau soal yang sangat memperhatikan semesta. Bila semesta yang ditetapkan tidak diperhatikan, maka akan sangat besar kemungkinan yang diberikan akan salah.

Contohnya, pada jam empatan, berapakah $3+7=$ ?, kita harus menyadari pada semesta berapakan kita bekerja

Di alam semesta ini, seluruh umat manusia diciptakan berkelompok-kelompok, berbangsa-bangsa dengan segala perbedaannya. Setiap kelompok mempunyai aturan-aturan tertentu yang wajib ditaati oleh segenap angota kelompok. Dalam bersikap dan bertutur kata kita harus memperhatikan di mana kita berada dan bagaimana aturan yang berlaku dalam kelompok tersebut. Secara umum, dimanapun kita berada harus dapat menyesuaikan diri dengan lingkungan tempat kita berada. Jadi dengan selalu menyadari semesta dalam matematika, dapat digunakan dengan selalu menyadari di mana kita berada dan apa yang berlaku dalam semesta

\section{Pembelajaran Matematika}

Pembelajaran berdasarkan makna leksikal berarti proses, cara, perbuatan mempelajari [6]. Pembelajaran ialah suatu proses yang dilakukan oleh individu untuk memperoleh suatu perubahan perilaku yang baru secara keseluruhan, sebagai hasil dari pengalaman individu itu sendiri dalam interaksi dengan lingkungannya [7]. Pembelajaran terdiri atas semua aktivitas bertujuan dari dosen yang diarahkan untuk menghasilkan, merangsang, atau mempermudah belajar oleh mahasiswa Pembelajaran berkenaan dengan bagaimana dan apa saja metode-metode, materi-materi, strategi- strategi, tugas-tugas, dan insentif-insentif yang dapat diterapkan untuk mendorong belajar [8]. Jadi, mahasiswa diharapkan mengalami perubahan ke arah yang lebih baik setelah mengalami proses pembelajaran.

Matematika berasal dari bahasa latin manthanein atau mathema yang berarti belajar atau hal yang dipelajari. Matematika dalam bahasa Belanda disebut wiskunde atau ilmu pasti, yang kesemuanya berkaitan dengan penalaran. Ciri utama matematika adalah penalaran deduktif, yaitu kebenaran suatu konsep atau pernyataan diperoleh sebagai akibat logis dari kebenaran sebelumnya sehingga kaitan antar konsep atau pernyataan dalam matematika bersifat konsisten [3]. Matematika berfungsi mengembangkan kemampuan menghitung, mengukur, menurunkan dan menggunakan rumus 
matematika yang diperlukan dalam kehidupan sehari-hari melalui materi pengukuran dan geometri, aljabar, dan trigonometri. Matematika juga berfungsi mengembangkan kemampuan mengkomunikasikan gagasan dengan bahasa melalui model matematika yang dapat berupa kalimat dan persamaan matematika, diagram, grafik atau tabel.

Dari pengertian di atas maka dapat disimpulkan bahwa pembelajaran matematika adalah serangkaian proses yang melibatkan dosen matematika dan mahasiswanya yang diarahkan untuk menghasilkan, merangsang, atau mempermudah belajar matematika oleh mahasiswa. Mahasiswa diharapkan mengalami perubahan ke arah yang lebih baik setelah mengalami proses pembelajaran matematika. Dengan kata lain mahasiswa diharapkan dapat mencapai tujuan pembelajaran matematika yang telah ditentukan.

\section{Pendidikan Karakter}

Pendidikan adalah suatu upaya sadar dan sistematis untuk mengembangkan potensi peserta didik secara optimal. Pendidikan adalah usaha masyarakat dan bangsa dalam mempersiapkan generasi mudanya bagi keberlangsungan kehidupan masyarakat dan bangsa yang lebih baik di masa depan. Keberlangsunagn ini ditandai oleh pewarisan budaya dan karakter yang telah dimiliki masyarakat dan bangsa. Dalam proses pendidikan budaya dan karakter bangsa secara aktif peserta didik secara aktif mengembangkan potensi dirinya, melakukan proses internalisasi dan penghayatan nilai-nilai menjadi kepribadian mereka dalambergaul di masyarakat, dan mengembangkan kehidupan bangsa yang bermartabat. Usaha sadar ini tidak boleh dilepaskan dari lingkungan peserta didik berada, terutama dari lingkungan budayanya karena peserta didik hidup tak terpisahkan dalam lingkungan dan bertindak sesuai dengan kaidah-kaidah budayanya.

Karakter adalah watak, tabiat, akhlak, atau kepribadian seseorang yang terbentuk dari hasil internalisasi berbagai kebajikan yang diyakini dan digunakan sebagai landasan untuk cara pandang, berpikir, bersikap, dan bertindak [13]. Kebajikan terdiri atas sejumlah nilai, moral, dan norma seperti jujur, berani bertindak, dapat dipercaya, dan hormat kepada orang lain. Interaksi seseorang dengan orang lain menumbuhkan karakter masyarakat dan bangsa. Oleh karena itu, pengembangan karakter bangsa hanya dapat dilakukan melalui pengembangan karakter individu seseorang. Akan tetapi, karena manusia hidup dalam lingkungan sosial dan budaya tertentu, maka pengembangan karakter individu hanya dapat dilakukan dalam lingkungan sosial budaya yang bersangkutan. Artinya pengembangan karakter bangsa hanya dapat dilakukan dalam setiap proses pendidikan yang tidak dapat dilepaskan dari lingkungan sosial budaya masyarakat.

Berdasarkan pengertian di atas dapat disimpulkan bahwa pendidikan karakter adalah pendidikan yang mengembangkan nilai-nilai karakter bangsa pada diri peserta didik sehingga mereka memiliki nilai dan karakter sebagai karakter dirinya, menerapkan nilai-nilai tersebut dalam kehidupan dirinya sebagai anggota masyarakat dan warga negara yang religius, nasionalis, produktif, dan kreatif.

Nilai-nilai yang dikembangkan dalam pendidikan karakter adalah sebagai berikut [13]:

Tabel 1 Nilai dan Deskripsi Nilai Pendidikan Karakter Bangsa.

\begin{tabular}{ll}
\hline Nilai & Deskripsi \\
\hline 1. Religius & $\begin{array}{l}\text { Sikap dan perilaku yang patuh dalam melaksanakan ajaran agama yang dianutnya, } \\
\text { toleran terhadap pelaksanaan ibadah agama lain dan hidup rukun dengan pemelik } \\
\text { agama lain }\end{array}$ \\
$\begin{array}{l}\text { Perilaku yang didasarkan pada upaya menjadikan dirinya sebagai orang yang selalu } \\
\text { dapat dipercayadalam perkataan, tindakan, dan pekerjaan }\end{array}$ \\
$\begin{array}{l}\text { 2. Jujur } \\
\text { 3. Toleransi dan tindakan yang menghargai perbedaan agama, suku, etnis, pendapat, sikap, } \\
\text { 4. Disiplin }\end{array} \quad \begin{array}{l}\text { Tindakan yang menunjukkan perilaku tertib, dan patuh pada berbagai ketentuan dan } \\
\text { peraturan } \\
\text { Perilaku yang menunjukkan upaya sungguh-sungguh dalam mengatasi berbagai hambatan } \\
\text { belajar dan tugas, serta menyelesaikan tugas dengan sebaik-baiknya }\end{array}$
\end{tabular}


6. Kreatif

7. Mandiri

8. Demokratis

9. Rasa ingin tahu

10. Semangat kebangsaan

11. Cinta tanah air

12. Menghargai prestasi

13. Bersahabat/ komunikatif

14. Cinta damai

15. Gemar membaca

16. Peduli Lingkungan

17. Peduli sosial

18. Tanggung jawab
Berpikir dan melakukan sesuatu untuk menghasilkan cara atau hasil baru dari sesuatu yang telah dimiliki

Sikap dan perilaku yang tidak mudah tergantung pada orang lain dalam menyelesaikan tugas-tugas

Cara berpikir, bersikap, dan bertindak yang menilai sama hak dan kewajiban dirinya dan orang lain

Sikap dan tindakan yang selalu berupaya untuk mengetahui lebih mendalam dan meluas dari sesuatu yang dipelajarinya, dilihat, dan didengar

Cara berpikir, bertindak, dan berwawasan yang menempatkan kepentingan bangsa dan negara di atas kepentingan diri dan kelompoknya

Cara berpikir, bersikap, dan berbuat yang menunjukkan kesetiaan, kepedulian, dan penghargaan yang tinggi terhadap bahasa, lingkungan, fisik, sosial, budaya, ekonomi, dan politik bangsa

Sikap dan tindakan yang mendorong dirinya untuk menghasilkan sesuatu yang berguna bagi masyarakat, dan mengakui, serta menghormati keberhasilan orang lain

Tindakan yang memperlihatkan rasa senang berbicara, bergaul, dab bekerjasama dengan orang lain

Sikap, perkataan, dan tindakan yang menyebabkan orang lain merasa senang dan aman atas kehadiran dirinya

Kebiasaan menyediakan waktu untuk membaca berbagai bacaan yang memberikan kebajikan bagi dirinya

Sikap dan tindakan yang selalu berupaya mencegah kerusakan pada lingkungan alam di sekitarnya, dan mengembangkan upaya-upaya untuk memperbaiki kerusakan alam yang sudah terjadi

Sikap dan tindakan yang selalu ingin memberi bantuan pada orang lain dan masyarakat yang membutuhkan

Sikap dan perilaku seseorang untuk melaksanakan tugas dan kewajibannya yang seharusnya dia lakukan terhadap diri sendiri, masyarakat, lingkungan (alam, soaial, dan budaya), negara dan Tuhan Yang Maha Esa

\section{Pembelajaran Matematika untuk Peserta Didik Sekolah Dasar}

Standar Kompetensi Lulusan Sekolah Dasar (SD) atau Madrasah Ibtidaiyah (MI) adalah sebagai berikut [3].

1. Memahami konsep bilangan bulat dan pecahan, operasi hitung dan sifat-sifatnya, serta menggunakannya dalam pemecahan masalah kehidupan sehari-hari.

2. Memahami bangun datar dan bangun ruang sederhana, unsur-unsur dan sifat-sifatnya, serta menerapkannya dalam pemecahan masalah kehidupan sehari-hari.

3. Memahami konsep ukuran dan pengukuran berat, panjang, luas, volume, sudut, waktu, kecepatan, debit, serta mengaplikasikannya dalam pemecahan masalah kehidupan sehari-hari.

4. Memahami konsep koordinat untuk menentukan letak benda dan menggunakannya dalam pemecahan masalah kehidupan sehari-hari.

5. Memahami konsep pengumpulan data, penyajian data dengan tabel, gambar dan grafik (diagram), mengurutkan data, rentangan data, rerata hitung, modus, serta menerapkannya dalam pemecahan masalah kehidupan sehari-hari.

6. Memiliki sikap menghargai matematika dan kegunaannya dalam kehidupan.

7. Memiliki kemampuan berpikir logis, kritis, dan kreatif.

Untuk mencapai kompetensi tersebut di atas, diperlukan pendidik yang kompeten. Selain itu, tidak terlepas dari kompetensi tersebut, namun juga dapat membentuk karakter peserta didik dapat dilakukan dengan melalui pembelajaran matematika pada materi-materi sesuai dengan yang ada dalam standar kompetensi lulusan terseburt di atas. 
Untuk peserta didik Sekolah Dasar, misalnya pada pokok bahasan bilangan, operasi bilangan (penjumlahan, pengurangan, perkalian, dan penjumlahan), statistik, pengukuran dan lain-lain dapat digunakan untuk mengajarkan anti korupsi pada peserta didik.

Dengan mengambil tema "Bahaya korupsi" atau "Awas Korupsi" beberapa pokok bahasan dapat dibahas dengan berdasarkan tema tersebut. Guru dapat memfasilitasi peserta didik mencapai kompetensi dasar yang sudah ditentukan. Sebelumnya guru harus memberi kesempatan pada peserta didik untuk mendiskusikan dan membuat suatu kesepakatan tentang definisi korupsi. Pada diskusi ini peserta didik berlatih mengkomunikasikan ide-idenya dan secara bersama-sama membuat kesepakatan tentang definisi tersebut. Dari kesepakatan tersebut, peserta didik akan dapat mengidentifikasi contoh dan bukan contoh dari suatu tindakan korupsi. Dengan berdiskusi sesama mereka. Misalnya "Apakah teman yang tidak membayarkan uang sekolah ke guru adalah suatu tindak korupsi?", "Apakah jika kita jajan tidak membayar juga termasuk tindak korupsi?" dan contoh-contoh lain yang dekat dengan kehidupan mereka.

Misalnya pokok bahasan bilangan, diharapkan anak dapat mengerti nilai dari suatu bilangan (bilangan yang dipilih disesuaikan dengan tingkat kelasnya). Pada pembahasan ini peserta didik diajak untuk memahami seberapa besar nilai dari suatu bilangan. Pada pembelajaran ini, guru tidak hanya menginformasikan bahwa satu juta mempunyai enam nol (1.000.000), satu milyar mempunyai sembilan nol (1.000.000.000), tetapi peserta didik juga dibantu memahami seberapa besar nilainya. Hal ini untuk melatih number sense peserta didik. Contoh yang dekat dengan kehidupan mereka akan mempermudah peserta didik memahami makna dan dampak tindak korupsi, untuk membuat mereka menjadi generasi anti korupsi.

Pada saat ada berita di koran bahwa KPK berhasil menggagalkan rencana penyelundupan ganja senilai 100 miliar. Guru dapat merumuskan pertanyaan berapa besarkah nilai uang 100 miliar tersebut? Anak dapat difasilitasi melakukan kegiatan investigasi sesuai dengan kehidupan mereka, misalnya dengan mengidentifikasi kebutuhan sekolah mereka (harga buku-buku pelajaran, alat olahraga, bangku sekolah, dan lain-lain). Dengan demikian, mereka diharapkan dapat memahami bahwa uang sebesar 100 miliar tadi dapat digunakan untuk berapa besar kebutuhan sekolah mereka. Dengan memaknai secara mendalam tentang bilangan, peserta didik diharapkan dapat mengerti berapa nilai kerugian korupsi yang ditimbulkan bagi dirinya dan masyarakat lainnya. Pada akhirnya para peserta didik diharapkan dapat lebih cepat memahami permasalahan masyarakat dan mengkritisi kejadian yang ada di sekitar mereka. Dengan demikian, moral anak terhadap korupsi dapat dibangun sejak dini dan mereka akan bisa diharapkan sebagai generasi masa depan yang anti korupsi.

\section{Pembelajaran untuk Peserta Didik Sekolah Menengah}

Dengan memahami logika matematika dan dasar keagamaan yang benar akan semakin meningkatkan keimanan dan ketaqwaan kita pada Alloh swt. Sebagai contoh misalnya bagi peserta didik Sekolah Menengah yang sedang mempelajari logika matematika pada pembahasan konjungsi dapat menggunakan hafalan surat-surat pendek misalnya Quran surat Al Ashr yang berbunyi:

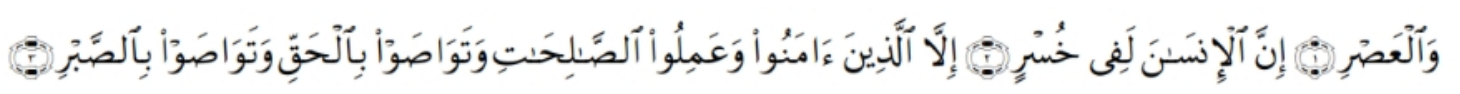

Artinya: (1). Demi masa. (2). Sesungguhnya manusia itu benar-benar dalam kerugian, (3). Kecuali orang-orang yang beriman dan mengerjakan amal saleh dan nasehat menasehati supaya mentaati kebenaran dan nasehat menasehati supaya menetapi kesabaran.

Jika kita telaah ayat tersebut dengan menggunakan hukum logika matematika bahwa konjungsi dari dua pernyataan akan bernilai logik benar jika nilai kebenaran dari kedua pernyataan tersebut benar. Perhatikan tabel implikasi berikut.

\begin{tabular}{|c|c|c|}
\hline $\mathbf{p}$ & $\mathbf{q}$ & $\mathbf{P} \rightarrow \mathbf{q}$ \\
\hline $\mathrm{B}$ & $\mathrm{B}$ & $\mathrm{B}$ \\
\hline $\mathrm{B}$ & $\mathrm{S}$ & $\mathrm{S}$ \\
\hline $\mathrm{S}$ & $\mathrm{B}$ & $\mathrm{S}$ \\
\hline $\mathrm{S}$ & $\mathrm{S}$ & $\mathrm{S}$ \\
\hline
\end{tabular}


Jika dikaji secara lebih mendalam dari ayat di atas, sesuai dengan hukum konjungsi, maka kita tidak akan berada dalam kerugian jika kita beriman dan beramal sholeh. Jika hanya beriman saja tanpa beramal sholeh maka masih berada dalam kerugian, atau sebaliknya jika beramal sholeh saja tanpa beriman, kitapun tetap dalam kerugian, apalagi jika tidak melakukan kedua-duanya, maka jelaslah akan berada dalam kerugian yang besar.

Keimanan adalah keyakinan besar sedangkan beramal sholeh adalah tindakan nyata dalam keimanan itu. Iman berfungsi untuk memberikan pengaruh positif dalam menunaikan kewajiban yang berhubungan dengan harta benda, mengakui kesalahan dan bersedia menerima hukuman, menegakkan hukuman, dan memelihara amanah, perintah dan keadilan, perniagaan, dan hubungan sehari-hari serta dalam menolong dan mengutamakan kawan. Amal sholeh ditempatkan pada urutan kedua setelah kita beriman. Amal sholeh adalah perbuatan yang dianggap baik oleh manusia sesuai dengan fitrahnya untuk membedakan yang baik dan yan buruk.

Selain dengan menggunakan ayat di atas dapat juga ditelaah Al Quran surat Mujadillah ayat 11 yang berbunyi sebagai berikut:

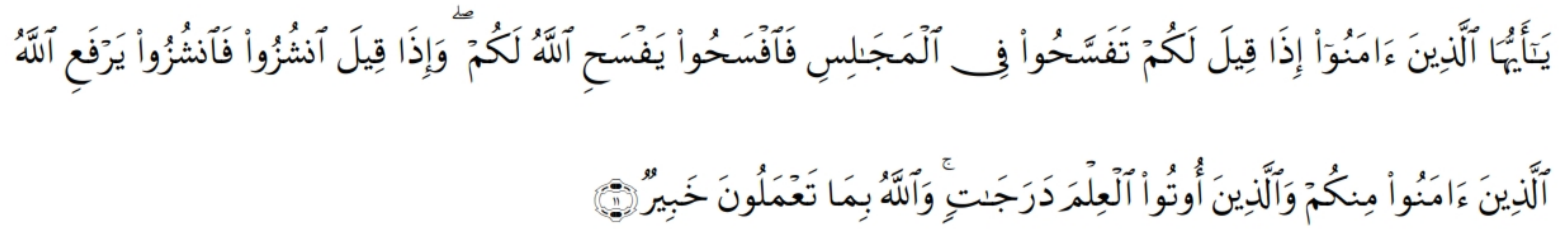

Artinya: Hai orang-orang beriman apabila dikatakan kepadamu: "Berlapang-lapanglah dalam majlis", Maka lapangkanlah niscaya Allah akan memberi kelapangan untukmu. dan apabila dikatakan: "Berdirilah kamu", Maka berdirilah, niscaya Allah akan meninggikan orang-orang yang beriman di antaramu dan orang-orang yang diberi ilmu pengetahuan beberapa derajat. dan Allah Maha mengetahui apa yang kamu amalkan .

Berdasarkan ayat di atas maka dapat diketahui jaminan dari Alloh swt bahwa Alloh swt akan meninggikan derajat orang-orang yang beriman dan berilmu. Jadi dengan beriman saja belumlah cukup untuk meninggikan derajat di mata Alloh swt. Demikian juga, dengan berilmu saja meskipun dengan sederetan gelar kesarjanaan jika tanpa iman maka tidak akan menambah derajatnya di sisi Alloh swt, namun justru kemungkinan akan memerosotkannya ke jurang kehinaan, sebab tanpa iman ilmu yang dimiliki kemungkinan akan disalahgunakan untuktindakan yang bertentangan dengan aturan negara bahkan agama. Sehingga tindakannya hanya akan menimbulkan kerusakan di muka bumi.

Kata-kata kunci yang bisa ditarik dari ayat tersebut adalah iman, ilmu, dan amal. Ketiganya menjadi satu rangkaian sistemik dalam struktur kehidupan setiap muslim lebih mementingkan yang satu dari yang lain akan melahirkan kehidupan yang timpang.

\section{Pembelajaran Matematika untuk Mahasiswa di Perguruan Tinggi}

Bagi mahasiswa calon guru, dapat dimotivasi dengan menanyakan mengapa kita perlu belajar matematika. Dengan sederetan gelar kesarjanaan yang disandang para ahli maka tetap akan merasa kecil tak berdaya, jika kita belajar matematika untuk mengakui kebesaran Alloh swt. Dalam Al Quran surat Ibrahim (14) ayat 51 yang berbunyi:

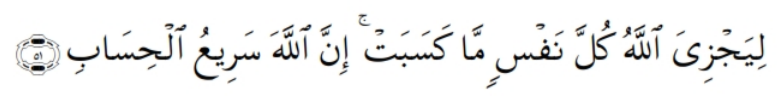

Artinya: Agar Allah memberi pembalasan kepada tiap-tiap orang terhadap apa yang ia usahakan. Sesungguhnya Allah Maha cepat hisab-Nya .

Dari ayat di atas dapat diketahui bahwa di dunia ini di antara para pakar matematika tidak ada yang akan dapat mengalahkan Alloh swt dalam hal kecepatan menghitung sesuatu. Bahkan pada tingkat kecermatan dan ketelitian Alloh swt adalah Maha Teliti termasuk ketelitian Alloh swt dalam menghitung dan membalas amal umat manusia sebagaimana firman Nya dalam Al Quran surat Al Zalzalah ayat 7-8 yang berbunyi sebagai berikut: 


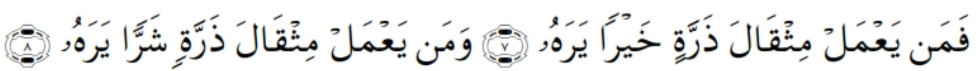

Artinya: (7). Barangsiapa yang mengerjakan kebaikan seberat dzarrahpun, niscaya Dia akan melihat (balasan)nya. (8). Dan barangsiapa yang mengerjakan kejahatan sebesar dzarrahpun, niscaya Dia akan melihat (balasan)nya pula.

Walaupun dalam matematika ada istilah galat, limit, dan lain-lain, tetapi tetap saja tidak akan dapat menandingi Alloh swt dalam hal ketelitian dan kecermatan. Alloh Maha Besar, kita manusia adalah kecil, tidak boleh sombong, dan harus tunduk pada Alloh swt. Masih banyak manusia yang memiliki keinginan untuk melakukan rasionalisasi terhadap nilai-nilai Al Quran. Jika tidak rasional maka mereka tidak siap dan sulit untuk menerimanya. Misalnya hukum hak waris yang memberikan hak laki-laki lebih banyak daripada perempuan, diharamkannya riba, diwajibkannya manusia mengeluarkan zakat, dan lain-lain. Semua hal menyangkut kehidupan manusia sudah diatur Alloh swt dalam Al Quran dan bersifat mutlak, tapi mengapa masih ada manusia yang menawar-nawar lagi? Dalam matematika ada pengertian pangkal yang disepakati kebenaran dan keberadaanya tanpa ditawar, diperdebatkan dan dibuktikan kebenarannya. Pola pikir inilah yang akan membantu mahasiswa dalam mengakui kebenaran Al Quran tanpa harus dibuktikan karena kebenaran Al Quran bersifat mutlak. Oleh karena itu, sekaranglah saatnya bagi kita para pendidik matematika untuk membangun konstruksi berpikir matematika menuju konstruksi berpikir yang Qurani.

\section{Kesimpulan}

Berdasarkan paparan tersebut di atas dapat disimpulkan bahwa:

1. Dengan memperhatikan karakteristik dari matematika dan dengan pembelajaran matematika yang integratif, maka pembelajaran matematika dapat membentuk karakter peserta didik di antaranya nilai-nilai kesepakatan, ketaatasasan/konsistensi, deduksi, dan semesta.

2. Karakter peserta didik yang dapat dibentuk dengan pembelajaran matematika di antaranya adalah religius, jujur, toleransi, disiplin, kreatif, demokratis, rasa ingin tahu, semangat kebangsaan, dan komunikatif.

\section{Referensi}

[1] Bell, Frederick H. 1981. Teaching and Learning Mathematics (in Secondary Schools). Wm. C. Brown Company. Dubuque. lowa.

[2] Ibrahim dan Suparni. 2008. Strategi Pembelajaran Matematika. POKJA Akademik. UIN Sunan Kalijaga. Yogyakarta.

[3] Pusat Kurikulum, Badan Penelitian dan Pengembangan Departemen Pendidikan Nasional, 2003. Kurikulum 2004 Standar Kompetensi Mata Pelajaran Matematika SMP \& MTs. Jakarta: Pusat Kurikulum, Balitbang Depdiknas.

[4] Soedjadi, R. 1985. Mencari Strategi Pengelolaan Pendidikan Matematika Menyongsong Tinggal Landas Pembangunan Indonesia. Surabaya.

[5] Soedjadi, R. 1995. Matematika Sekolah Lanjutan Tingkat Pertama sebagai wahana pendidikan dan pembudayaan penalaran. Surabaya.

[6] Suprijono, Agus, 2009. Cooperative Learning: Teori dan Aplikasi PAIKEM. Yogyakarta: Pustaka Pelajar.

[7] Surya, H. Mohammad. 2004. Psikologi Pembelajaran dan Pengajaran, (Bandung: Pustaka Bani Quraisy).

[8] Wahyudin. 2008. Pembelajaran dan Model-model Pembelajaran Seri 3. Jakarta: CV. IPA Abong.

[9] 2009. A/ Quran. Departemen Agama RI

[10] 2006. Kerangka Dasar Keilmuan dan Pengembangan Kerikulum UIN Sunan Kalijaga Yogyakarta. Pokja Akademik.

[11] 2006. Kurikulum KTSP. Departemen Pendidikan Nasional. Jakarta

[12] 2003. UU no 20 tahun 2003 tentang Sistem Pendidikan Nasional. Deprtemen Pendidikan. Jakarta.

[13] Jakarta 2010. Pengembangan Pendidikan budaya dan karakter bangsa. Balitbang Kemendiknas. 